\title{
Segítheti-e a növényfajok invázióját az ellenségeik hiánya? - Irodalmi áttekintés a közönséges selyemkórót és Európában őshonos rokonait, a méreggyilokfajokat fogyasztó rovarokról
}

\author{
${\text { Berki Boglárka }{ }^{1 *} \text { és Csecserits Anikó }}^{2}$ \\ ${ }^{1}$ Eötvös Loránd Tudományegyetem, Növényrendszertani, Ökológiai és Elméleti Biológiai \\ Tanszék, 1117 Budapest, Pázmány Péter sétány 1/C \\ ${ }^{2}$ Ökológiai Kutatóközpont, Ökológiai és Botanikai Intézet, \\ 2163 Vácrátót, Alkotmány u. 2-4. \\ *E-mail: berki.boglarka@ecolres.hu
}

\begin{abstract}
Összefoglaló: A közönséges selyemkóró (Asclepias syriaca) hazánk egyik legveszélyesebb lágyszárú évelő inváziós faja. Legközelebbi, európai rokonai a méreggyilokfajok (Vincetoxicum spp.), melyek közül kettő inváziós Észak-Amerikában. Ezek a növényfajok sok energiát fektetnek a rovarok elleni kémiai védekezésbe, így felmerül, hogy sikeres inváziójukat a specialista rovarfogyasztók hiánya is segíti. Szisztematikus irodalmi áttekintéssel összevetettük a közönséges selyemkórót és négy méreggyilokfajt az eredeti és új elterjedési területen fogyasztó rovar-közösséget. Az eredeti hazájában a selyemkórót tíz, a méreggyilokfajokat pedig nyolc tápnövény-specialista, továbbá számos generalista rovarfaj fogyasztja. Az új elterjedési területükön még egyik növényfaj specialista fogyasztói sem jelentek meg, csak generalista fogyasztókat figyeltek meg rajtuk. Ez alapján e növényfajok sikeres inváziójához a specialista fogyasztóik hiánya is hozzájárulhatott.
\end{abstract}

Kulcsszavak: Asclepias syriaca, Vincetoxicum spp., növényevő rovarok, növény-rovar közötti kölcsönhatás, növényi védekezési rendszerek

\section{Bevezetés}

Az inváziós fajok, ezen belül az inváziós növények terjedése világszerte az egyik legfontosabb oka a biodiverzitás csökkenésének, így sokszor súlyos természetvédelmi problémát jelentenek (Kolar és Lodge 2001, Stout és Morales 2009, You et al. 2014, IUCN 2000). Az idegenhonos fajok behozatalának vagy behurcolásának legfontosabb útja a globális kereskedelem, a közlekedés, valamint a mezőgazdaság, ezen belül különösen a kertészet (Hulme 2009). A behurcolás vagy betelepítés után számos idegenhonos faj elkezd önállóan terjedni. Azokat a nem őshonos 
fajokat tekintjük inváziós vagy özönfajnak, amelyek sikeresen tudnak alkalmazkodni az új környezet feltételeihez, szaporodóképes populációt hoznak létre és monoton terjednek, ezáltal elözönlik az új élőhelyüket (Richardson et al. 2000a, Pysek et al. 2004, Jeschke 2014).

Amikor egy inváziós növényfaj elterjed egy területen, az adott élőhelyre számos mechanizmuson keresztül gyakorolhat hatást, ezáltal veszélyeztetheti az őshonos fajokat, közösségeket (Pimentel et al. 2005), ami akár egyes öshonos fajok teljes eltünéséhez vezethet (Pyšek és Pyšek 1995, Richardson et al. 2000b). Az inváziós fajok az őshonos növényekre egyrészt fizikailag hatnak (például leárnyékolással) és versenyeznek velük az abiotikus erőforrásokért (például tápanyagok, fény, víz) (Levine et al. 2003, Stout és Morales 2009). Másrészt allelopátiás vegyületeket is termelhetnek, amelyek csökkentik az öshonos növényfajok reprodukciós sikerét: gátolják a magok csírázását vagy a fiatal egyedek növekedését (Hierro és Callaway 2003).

Az inváziós növényfajok nemcsak közvetlenül hatnak az öshonos növényközösségekre, hanem az állatközösségeken keresztül is, átalakítva a fajok közti korábbi kapcsolatrendszert (Bascompte és Jordano 2007, Stout et al. 2017). Elöfordulhat, hogy az új elterjedési területen nincsenek jelen az inváziós növényfajt fogyasztó táplálékspecialista rovarfajok (továbbiakban specialista rovar: csak az adott növényfajt vagy nemzetséget fogyasztó rovar, míg generalista rovar: több növényfajt és nemzetséget is fogyasztó rovar), ami előnyt jelent a növényfaj számára. Ezt a jelenséget írja le az „ellenségektől való megszabadulás”, azaz angolul „enemy release” hipotézis (Maron és Vilà 2001, Keane és Crawley 2002, Colautti et al. 2004), mely szerint az inváziós fajok sikerességének egyik lehetséges oka, hogy az új környezetben megszabadulnak a rájuk specializálódott fogyasztóktól és a fogyasztók által terjesztett kórokozóktól. Ezek a specialista fogyasztók az eredeti elterjedési területen együtt fejlődtek az adott növényfajjal, és ott csökkenthették annak sikerességét. Az újonnan kolonizált területeken a megtelepedett inváziós növényekre kisebb nyomás nehezedhet a fogyasztók részéről, hiányozhatnak a rájuk specializálódott fajok. Így az őshonos növényfajokhoz képest előnyre tehetnek szert, ami hozzájárulhat a sikerességükhöz (Agrawal és Kotanen 2003, Parker et al. 2012). Az ellenségektől való megszabadulás hipotézisét néhány növényfaj esetén terepi adatokon alapuló kutatás is igazolta (például Wolfe 2002, Callaway és Ridenour 2004).

A növények különféle mechanikai és kémiai módszerekkel védekeznek az őket fogyasztó állatfajok ellen (War et al. 2012). A mechanikai védelemi rendszert tüskék, tövisek, szőrök és megvastagodott levelek alkotják. A kémiai védekezési módoknak pedig két alapvető típusát lehet elkülöníteni: A konstitutív, azaz mindig jelen lévő, és az indukált, azaz sérülést követően fakultatív módon terme- 
lődő vegyületekkel történő védekezést. Az indukált növényi védekezést számos hatás kiválthatja, és sok esetben a növényi válaszok specifikusak a sérülésekre (Agrawal és Fishbein 2006, Rasmann et al. 2009). Az indukált növényi válasz nem jellemző olyan fajok esetében, amelyeket a növényevők nagy egyed- és fajszámban fogyasztanak; ezek a fajok inkább konstitutív védekező mechanizmust alkalmaznak. Azok az inváziós fajok viszont, melyeknél jelentős szerepe van az indukált kémiai védekezésnek, előnyt élvezhetnek az új környezetben specialista fogyasztójuk hiánya miatt (Agrawal és Fishbein 2006, Rasmann et al. 2009).

Ugyanakkor előfordulhat, hogy az inváziós növények a fogyasztóiktól csak ideiglenesen szabadultak meg, mivel az eredeti elterjedési területükön élő specialista fogyasztóik is megjelenhetnek az új elterjedési területen (da Ros et al. 1993, Keane és Crawley 2002). Továbbá az új elterjedési területen élő őshonos növényevők is áttérhetnek az új inváziós növényfajok fogyasztására, különösen akkor, ha az inváziós növényekkel rokon őshonos növényfajok is előfordulnak az adott helyen (Tabashnik 1983, Thomas et al. 1987, Maron és Vilá 2001, Agosta 2006).

Bár néhány inváziós faj esetén már igazolták (Han et al. 2008, Jogesh et al. 2008, Cincotta et al. 2009), hogy a sikerességük mögött részben a „ellenségeiktől való megszabadulás" állhat, további inváziós fajok esetén is érdemes megvizsgálni ezt a lehetőséget, mivel az erre vonatkozó információ akár a természetvédelmi kezelések során is hasznosítható.

Az adott inváziós növényfajt eredeti elterjedési területén fogyasztó rovarfajok és gazdaspecifikusságuk ismerete a biológiai védekezési eljárások kidolgozása során fontos (Julien és Griffiths 1998, McFadyen 1998). A rovarok tápnövényeinek megismerése szükséges annak meghatározásában, hogy egy rovar alkalmazható-e az adott inváziós növény ellen (Haye et al. 2005). Néhány inváziós növényfaj elleni védekezés során az őket fogyasztó rovarfajokat sikeresen használják biológiai védekezési programokban (Stinson et al. 1994, Ding et al. 2006, Wang et al. 2008, Herrick et al. 2012).

Hazánkban az egyik legveszélyesebb lágyszárú évelő inváziós faj az ÉszakAmerikából származó közönséges selyemkóró (Asclepias syiriaca L., 1753; Botta-Dukát 2008). Az ellene alkalmazott mechanikai kezelések az eddigi tapasztalatok szerint rövid távon nem megfelelő hatékonyságúak, hiszen a kaszálás vagy szárzúzás után a selyemkóró újra kihajt (Vajda 2015). Egyelőre a kémiai kezelés tünik a hatékonyabbnak (Bhowmik 1994), amikor glifozát-tartamú szereket használnak tapadást és felszívódást segítő szerekkel kombinálva (Vadász 2015, Zalai et al. 2017). A növényvédőszereket körültekintően szükséges alkalmazni, hiszen a környezetre, a rovar- és növényközösségekre is káros hatással lehet (de Andréa et al. 2003). Azonban felmerülhet, hogy a közönséges selyemkóró ellen specialista fogyasztóját is fel lehet használni biológiai védekezésként. 
A közönséges selyemkóró legközelebbi Európában őshonos rokona a méreggyilok nemzetség (Vincetoxicum spp.), melynek két faja, a Vincetoxicum nigrum (Kartesz és Ghandhi, 1994) és V. rossicum ((Kleo.) Borhidi, 1966) az Egyesült Államokban inváziós. Ellenük jelenleg a széles hatásspektrumú herbicidek a leghatékonyabb védekezési eszközök, de ezek használata költséges és káros hatással lehet az ökoszisztémára (DiTommaso et al. 2013). Így az Egyesült Államokban táplálékspecialista rovarokat is alkalmaznak biológiai védekezés céljából a méreggyilokfajok ellen (Young és Weed 2014).

Az Észak-Amerikából származó közönséges selyemkóró és a vele közel rokon, Európából származó, de Észak-Amerikában inváziós méreggyilokfajok számos tulajdonságukban megegyeznek, így felmerül, hogy mindkét nemzetség inváziós sikeressége mögött esetleg az ellenségektől való megszabadulás állhat. Emiatt célul tüztük ki, hogy összehasonlítsuk a közönséges selyemkóró és vele rokonságban álló négy méreggyilokfaj, a hazánkban őshonos közönséges méreggyilok (Vincetoxicum hirundinaria [Medik., 1790]) és magyar méreggyilok (Vincetoxicum pannonicum [Borhidi] Holub, 1967), valamint az Európából származó, de az Egyesült Államokban invázióssá vált Vincetoxicum nigrum és Vincetoxicum rossicum eredeti és új elterjedési területén az őket fogyasztó rovarközösségeket.

Vizsgálatunkban arra kerestük a választ, hogy 1) mennyi táplálékspecialista és generalista rovarfajt találtak ezeken a növényfajokon az őshonos és az új elterjedési területükön; 2) követték-e ezeket a növényfajokat specialista fogyasztóik az új elterjedési területre; 3 ) történt-e gazdaváltás a specialista fogyasztóik esetén selyemkóróról méreggyilokfajokra és fordítva, akár az új, akár az őshonos elterjedési területen? Ezeket a kérdéseket az eddig publikált kutatások alapján, szisztematikus irodalmi áttekintéssel válaszoljuk meg.

\section{Anyag és módszer}

\section{A közönséges selyemkóró}

A selyemkóró (Asclepias) nemzetségnek 140 faja ismert, legtöbbjük trópusi elterjedésü, Európában őshonos fajuk nem él (Bagi és Bakacsy 2012). A közönséges selyemkóró Európában először 1629-ben jelent, meg mint dísznövény (Bagi 2004). (A faj részletes leírását lásd az 1. Online Függelékben.) Spontán terjedését a mediterrán régióból kezdte meg, és mára Európa 24 országában van jelen (http1). Magyarországon jelenleg a közönséges selyemkóró inváziós növényfajként van számon tartva, mivel az utóbbi évtizedekben jelentősen terjed (Csiszár 2012). A selyemkóró gyors terjedéséhez hozzájárulhat, hogy kevés rovarfaj tudja 
fogyasztani, hiszen különböző mechanikai és kémiai védekezési mechanizmusokat fejlesztett ki az őt károsító rovarok ellen. A rovarok táplálkozását befolyásolja a selyemkóró mechanikai védekező tulajdonságai közül a nagy levélszilárdsága és nagy fedőszőr-sürüsége (van Zandt és Agrawal 2004, Agrawal 2005). A selyemkóró leghatásosabb védekezési mechanizmusa azonban a kémiai védekezés. A növény minden föld feletti része tejnedvet (latex) tartalmaz, melynek legfontosabb alkotói különböző kardenolid-vegyületek. A kardenolidok keserü ízü szteroidok (szívglikozidok: aspeciozid, syriobiozid, calactin, calotropin). Nemcsak a tejnedvben, hanem kis mennyiségben a növény más szöveteiben is elöfordulnak, és a legtöbb rovar számára mérgezőek (Malcolm 1991, Rasmann és Agrawal 2009). A növény károsodása esetén a tejnedv speciális csatornákon (laticifer sejtekből álló tejcsöveken) keresztül jut el a károsodott területre, és egyfajta fizikai gátként korlátozza a növényevők táplálkozását (Malcolm 1991).

\section{A méreggyilokfajok}

Európában a selyemkóró legközelebbi őshonos rokonai a selyemkórófélék (Asclepiadaceae) családjába tartozó méreggyilokfajok (Vincetoxicum spp.). (A méreggyilokfajok részletes leírása a 2. Online Függelékben olvasható.) Európában a nemzetség tíz faja fordul elő (Markgraf 1972), hazánkban két fajuk őshonos: a közönséges és a magyar méreggyilok (Király 2009). Észak-Amerikában nem fordul elő őshonos méreggyilokfaj (Tewksbury et al. 2002), ugyanakkor két Európából származó méreggyilokfaj - a Vincetoxicum nigrum és Vincetoxicum rossicum - invázióssá vált (Tewksbury et al. 2002, DiTommaso et al. 2005, Weed et al. 2011, Laukkanen 2014). Mindkét méreggyilokfajt az 1800-as évek közepe táján dísznövényként vitték be Észak-Amerikába (Sheeley és Raynal 1996, DiTommaso et al. 2005, Biazzo és Milbrath 2019). Kertekből kiszabadult állományaik kolonizálták a természetes és mezőgazdasági területeket, és az elmúlt 40 év alatt inváziós fajjá váltak az USA északkeleti és középnyugati részén (DiTommaso et al. 2005, Biazzo és Milbrath 2019). A kolonizált területeken a méreggyilokfajok tömeges jelenléte negatív hatással van bizonyos ritka és veszélyeztetett növényfajokra (DiTommaso et al. 2005). Továbbá csökkentik a rovarok biodiverzitását is, például negatív hatással vannak a pompás királylepke (Danaus plexippus, Linnaeus, 1758) szaporodására (DiTommaso és Losey 2003, Casagrande és Dacey 2007).

A nemzetség fajai kevés rovarfaj számára szolgálnak tápnövényként, hiszen másodlagos anyagcseretermékeik között vannak mérgező glikozidok (például vincetoxin, aszklepiadin, Staerk et al. 2000, Muola et al. 2010), fenolos vegyületek (flavonoidok, klorogénsav és katechin-származékok) és alkaloidok (antofin és fenanthroindolizidin, Laukkanen et al. 2012). 
Az irodalmi áttekintés módszerei

A Web of Science (http2) és a Google Scholar (http3) adatbázisokban a közönséges selyemkóróra és a méreggyilokfajokra külön-külön kereséseket végeztünk.

A Web of Science elektronikus keresőrendszerében az 1975 és 2019 között megjelent publikációk címében és absztraktjában a következő keresési beállításokkal kerestünk: 1) „common milkweed” VAGY „Asclepias syriaca” ÉS „,herbivor*”; 2) „common milkweed” VAGY „Asclepias syriaca” ÉS ,plant-insect interactions”; 3) „common milkweed” VAGY „Asclepias syriaca” ÉS „defense system”; 4) „common milkweed” VAGY „Asclepias syriaca” ÉS ,insect*”. A találatokat szúkítettük „ecology”, ,plant sciences”, „,biodiversity conservation”, „environmental sciences” és „,biology” témakörökre. A négy keresés összesen 974 találatot eredményezett, ezek közül a cikkek címe és absztraktja alapján választottuk ki a leginkább releváns találatokat.

A Google Scholar adatbázisban kiegészítő keresést végeztünk. Az 1975 és 2019 között megjelent publikációk címében és absztraktjában ugyanazokkal keresési beállításokkal kerestünk, mint a Web of Science adatbázisban. A négy keresés 12980 találata közül a cikkek címe és absztraktja alapján választottuk ki a legrelevánsabbakat.

A méreggyilokfajokra a Web of Science elektronikus keresőrendszerében az 1975 és 2019 között megjelent publikációk címében és absztrakjában a következő keresési beállításokkal kerestünk: 1) „dog-strangling vine” VAGY „Vincetoxicum” ÉS ,herbivor*”; 2) „dog-strangling vine” VAGY ,Vincetoxicum” ÉS ,plantinsect interactions”; 3) ,dog-strangling vine" VAGY ,Vincetoxicum” ÉS ,defense system”; 4) „dog-strangling vine” VAGY ,Vincetoxicum” ÉS ,insect*”. A találatokat szükítettük „ecology”, „plant sciences”, „,biodiversity conservation”, environmental sciences” és „biology” témakörökre. A négy keresés összesen 128 találatot adott, ezek közül a cikk címe és absztraktja alapján választottuk ki a legrelevánsabbakat.

A méreggyilokfajokra szintén kiegészítő keresést végeztünk a Google Scholar adatbázisban. Az 1975 és 2019 között megjelent cikkek címében és absztraktjában ugyanazokkal keresési beállításokkal kerestünk, mint a Web of Science adatbázisban. A négy keresés során 408 találat közül a cikkek címe és absztraktja alapján választottuk ki a leginkább releváns találatokat.

A keresés során az irodalmakban említett növényevő rovarokat a rendelkezésre álló adatok alapján táplálkozásuk szempontjából két csoportba soroltuk. Az egyik csoportba kerültek azok, amelyek a vizsgált növényfaj (közönséges selyemkóró vagy méreggyilokfajok) vagy növénynemzetség (Asclepias, Vincetoxicum) fogyasztására specializálódtak. A továbbiakban specialistának nevezzük ezeket. A másik csoportba azokat soroltuk, amelyek több növénynemzetséget fogyasztanak, 
nemcsak a selyemkórót vagy a méreggyilokfajokat, így a táplálékul szolgáló növények megritkulásakor könnyen átváltanak más fajok fogyasztására. A továbbiakban ezeket generalistának nevezzük.

\section{Eredmények}

\section{A selyemkóró fogyasztói}

Észak-Amerikában jelenleg tíz közönséges selyemkórót fogyasztó specialista rovarfajt és 13 generalista rovart tartanak számon (1., 2. táblázat). Feltételezhetően több mint 400 rovarfaj fogyaszthatja a selyemkóró valamely részét, viszont ezek a rovarok nem lettek még faji szintig meghatározva (http4).

Európában öt őshonos rovarfajról mutatták ki, hogy a selyemkórót fogyasztja (3. táblázat). Ezeken kívül a selyemkórót számos levéltetüfaj és a nyugati virágtripsz (Frankliniella occidentalis Pergande, 1895) károsítja, amelyek világszerte elterjedt fajok, őshonos elterjedési területük sokszor nem is ismert vagy Európában is új jövevénynek számítanak és korábban rokon fajokkal is táplálkoztak. Közülük Európában legismertebb a leander-levéltetü (Aphis nerii Fonscolombe, 1841), és az uborka-levéltetü (Aphis gossypii Glover, 1877), melyek mind világszerte elterjedt fajok, így Észak-Amerikában is megtalálhatóak (3. táblázat).

Az eddigi kutatások alapján a tíz Észak-Amerikában őshonos, közönséges selyemkóróra specializálódott rovarfaj közül Európában még egy sem fordul elő.

1. táblázat. A közönséges selyemkórót fogyasztó rovarfajok száma.

\begin{tabular}{ccc}
\hline & Specialista fajok & Generalista fajok \\
\hline $\begin{array}{c}\text { Észak-Amerikában öshonos, közönséges selyem- } \\
\text { kórót fogyasztó rovarok }\end{array}$ & 10 & $\mathrm{~kb} .400$ \\
$\begin{array}{c}\text { Európában megjelent rovarok } \\
\text { Észak-Amerikában Vincetoxicum fajokról a se- } \\
\text { lyemkóróra váltott = selyemkóró új fogyasztója }\end{array}$ & 0 & 5 \\
$\begin{array}{c}\text { Európában őshonos, selyemkórót fogyasztó rovar } \\
\text { = selyemkóró új fogyasztója }\end{array}$ & 0 & $\mathrm{~kb} .40-50$ \\
\hline
\end{tabular}


2. táblázat. A közönséges selyemkórót legyakrabban fogyasztó rovarfajok az őshazájában (ÉszakAmerika).

\begin{tabular}{|c|c|c|c|c|}
\hline Faj neve & $\begin{array}{l}\text { Rendszertani } \\
\text { besorolás }\end{array}$ & $\begin{array}{l}\text { Táplálkozás } \\
\text { típusa }\end{array}$ & $\begin{array}{l}\text { Növényi rész } \\
\text { fogyasztása }\end{array}$ & Hivatkozás \\
\hline $\begin{array}{c}\text { Danaus plexippus } \\
\text { L., } 1758\end{array}$ & $\begin{array}{l}\text { Lepidoptera: } \\
\text { Nymphalidae }\end{array}$ & specialista & levelek, tejnedv & $\begin{array}{l}\text { van Zandt, Agrawal } \\
\text { 2004, Agrawal et al. } \\
\text { 2005, Holdrege } 2010\end{array}$ \\
\hline $\begin{array}{c}\text { Euchaetes egle } \\
\text { D., } 1773\end{array}$ & $\begin{array}{l}\text { Lepidoptera: } \\
\text { Erebidae }\end{array}$ & specialista & alsóbb levelek & $\begin{array}{c}\text { Bingham, Agrawal } \\
2010\end{array}$ \\
\hline $\begin{array}{c}\text { Rhyssomatus } \\
\text { lineaticollis } \\
\text { S., } 1824\end{array}$ & $\begin{array}{l}\text { Coleoptera: } \\
\text { Curculionidae }\end{array}$ & specialista & $\begin{array}{l}\text { fiatal levelek, } \\
\text { csúcsmerisztéma }\end{array}$ & $\begin{array}{l}\text { Fordyce, Malcolm } \\
\text { 2000, Agrawal } 2005\end{array}$ \\
\hline $\begin{array}{l}\text { Tetraopes } \\
\text { tetrophthalmus } \\
\text { F., } 1771\end{array}$ & $\begin{array}{l}\text { Colepotera: } \\
\text { Cerambycidae }\end{array}$ & specialista & $\begin{array}{l}\text { levelek, virágok, } \\
\text { gyökerek }\end{array}$ & $\begin{array}{l}\text { Matter 2001, Agrawal } \\
\text { 2004, van Zandt, } \\
\text { Agrawal } 2004, \text { Hold- } \\
\text { rege } 2010\end{array}$ \\
\hline $\begin{array}{c}\text { Labidomera } \\
\text { clivicollis } \\
\text { K., } 1837\end{array}$ & $\begin{array}{c}\text { Coleoptera: } \\
\text { Chrysomelidae }\end{array}$ & specialista & $\begin{array}{l}\text { levelek, levelek } \\
\text { erezete }\end{array}$ & $\begin{array}{l}\text { van Zandt, Agrawal } \\
\text { 2004, Agrawal et al. } \\
2005\end{array}$ \\
\hline $\begin{array}{l}\text { Lygaeus kalmii } \\
\text { S., } 1874\end{array}$ & $\begin{array}{l}\text { Hemiptera: } \\
\text { Lygaeidae }\end{array}$ & specialista & $\begin{array}{l}\text { levelek nedve, } \\
\text { termések }\end{array}$ & $\begin{array}{l}\text { van Zandt, Agrawal } \\
\text { 2004, Agrawal } 2005\end{array}$ \\
\hline $\begin{array}{c}\text { Oncopeltus } \\
\text { fasciatus } \text { D., } 1852\end{array}$ & $\begin{array}{l}\text { Hemiptera: } \\
\text { Lygaeidae }\end{array}$ & specialista & $\begin{array}{l}\text { virágbimbók, } \\
\text { fiatal termések }\end{array}$ & Chaplin, Chaplin 1981 \\
\hline $\begin{array}{l}\text { Aphis asclepiadis } \\
\text { F., } 1851\end{array}$ & $\begin{array}{l}\text { Hemiptera: } \\
\text { Aphididae }\end{array}$ & specialista & $\begin{array}{l}\text { fiatal hajtásainak } \\
\text { nedve }\end{array}$ & $\begin{array}{c}\text { Mooney et al. } 2008, \\
\text { Birnbaum, Abbot } 2018\end{array}$ \\
\hline $\begin{array}{l}\text { Myzocallis } \\
\text { asclepiadis } \\
\text { M., } 1879\end{array}$ & $\begin{array}{l}\text { Hemiptera: } \\
\text { Aphididae }\end{array}$ & specialista & $\begin{array}{l}\text { fiatal hajtásainak } \\
\text { nedve }\end{array}$ & Birnbaum, Abbot 2018 \\
\hline $\begin{array}{l}\text { Liriomyza } \\
\text { asclepiadis } \\
\text { S., } 1969\end{array}$ & $\begin{array}{c}\text { Diptera: } \\
\text { Agromyzidae }\end{array}$ & specialista & levelek & $\begin{array}{c}\text { van Zandt, Agrawal } \\
\text { 2004, Agrawal et al. } \\
2005\end{array}$ \\
\hline Aphis nerii F., 1841 & $\begin{array}{l}\text { Hemiptera: } \\
\text { Aphididae }\end{array}$ & generalista & levelek, szár & $\begin{array}{l}\text { Betz et al. 2000, } \\
\text { Mooney et al. } 2008\end{array}$ \\
\hline $\begin{array}{l}\text { Aphis gossypii } \\
\text { G., 1877, }\end{array}$ & $\begin{array}{l}\text { Hemiptera: } \\
\text { Aphididae }\end{array}$ & generalista & levelek, szár & Betz et al. 2000 \\
\hline $\begin{array}{l}\text { Aphis rumicis } \\
\text { L., } 1758\end{array}$ & $\begin{array}{l}\text { Hemiptera: } \\
\text { Aphididae }\end{array}$ & generalista & levelek, szár & Betz et al. 2000 \\
\hline $\begin{array}{l}\text { Aphis fabae } \\
\text { S., } 1763\end{array}$ & $\begin{array}{l}\text { Hemiptera: } \\
\text { Aphididae }\end{array}$ & generalista & levelek, szár & Betz et al. 2000 \\
\hline $\begin{array}{l}\text { Aphis spiraecola } \\
\text { P., } 1914\end{array}$ & $\begin{array}{l}\text { Hemiptera: } \\
\text { Aphididae }\end{array}$ & generalista & levelek, szár & Betz et al. 2000 \\
\hline $\begin{array}{l}\text { Aphis helianthi } \\
\text { M., } 1879\end{array}$ & $\begin{array}{l}\text { Hemiptera: } \\
\text { Aphididae }\end{array}$ & generalista & levelek, szár & Betz et al. 2000 \\
\hline
\end{tabular}


2. táblázat (folytatás). A közönséges selyemkórót legyakrabban fogyasztó rovarfajok az öshazájában (Észak-Amerika).

\begin{tabular}{|c|c|c|c|c|}
\hline Faj neve & $\begin{array}{l}\text { Rendszertani } \\
\text { besorolás }\end{array}$ & $\begin{array}{l}\text { Táplálkozás } \\
\text { típusa }\end{array}$ & $\begin{array}{l}\text { Növényi rész } \\
\text { fogyasztása }\end{array}$ & Hivatkozás \\
\hline $\begin{array}{c}\text { Toxoptera aurantii } \\
\text { B. } 1841\end{array}$ & $\begin{array}{l}\text { Hemiptera: } \\
\text { Aphididae }\end{array}$ & generalista & levelek, szár & Betz et al. 2000 \\
\hline $\begin{array}{c}\text { Aulacorthum solani } \\
\text { K., } 1843\end{array}$ & $\begin{array}{l}\text { Hemiptera: } \\
\text { Aphididae }\end{array}$ & generalista & levelek, szár & Betz et al. 2000 \\
\hline $\begin{array}{l}\text { Myzus persicae } \\
\text { S., } 1776\end{array}$ & $\begin{array}{l}\text { Hemiptera: } \\
\text { Aphididae }\end{array}$ & generalista & levelek, szár & Betz et al. 2000 \\
\hline $\begin{array}{c}\text { Brachycaudus } \\
\text { helichrysi K., } 1843\end{array}$ & $\begin{array}{l}\text { Hemiptera: } \\
\text { Aphididae }\end{array}$ & generalista & levelek, szár & Betz et al. 2000 \\
\hline $\begin{array}{c}\text { Macrosiphum } \\
\text { euphorbiae T., } \\
1878\end{array}$ & $\begin{array}{l}\text { Hemiptera: } \\
\text { Aphididae }\end{array}$ & generalista & levelek, szár & Betz et al. 2000 \\
\hline $\begin{array}{c}\text { Frankliniella } \\
\text { occidentalis P., } \\
1895\end{array}$ & $\begin{array}{l}\text { Thysanoptera: } \\
\text { Thripidae }\end{array}$ & generalista & levelek, szár & Betz et al. 2000 \\
\hline $\begin{array}{c}\text { Euschistus } \\
\text { variolarius P., } 1817\end{array}$ & $\begin{array}{l}\text { Hemiptera: } \\
\text { Pentatomidae }\end{array}$ & generalista & virágok, levelek & $\begin{array}{c}\text { Hughes, Bazzaz 1997, } \\
\text { Züst et al. } 2015\end{array}$ \\
\hline
\end{tabular}

3. táblázat. A közönséges selyemkórót leggyakrabban fogyasztó rovarokfajok az új elterjedési területén (Európa).

\begin{tabular}{|c|c|c|c|c|}
\hline Faj neve & $\begin{array}{l}\text { Rendszertani } \\
\text { besorolás }\end{array}$ & $\begin{array}{l}\text { Táplálkozás } \\
\text { típusa }\end{array}$ & $\begin{array}{l}\text { Növényi rész } \\
\text { fogyasztása }\end{array}$ & Hivatkozás \\
\hline $\begin{array}{c}\text { Spilosthetus }(= \\
\text { Lygaeus) equestris } \\
\text { L., } 1758 \text { (vörösfoltos } \\
\text { bodobács) }\end{array}$ & $\begin{array}{l}\text { Hemiptera: } \\
\text { Lygaeid; ae }\end{array}$ & generalista & $\begin{array}{l}\text { növényi nedv: } \\
\text { virágbimbók, } \\
\text { levelek, tokter- } \\
\text { més }\end{array}$ & Horváth 1984 \\
\hline $\begin{array}{c}\text { Tropidothorax } \\
\text { leucopterus } \text { G., } 1778 \\
\text { (vadpaprika bodobács) }\end{array}$ & $\begin{array}{l}\text { Hemiptera: } \\
\text { Lygaeidae }\end{array}$ & generalista & $\begin{array}{l}\text { növényi nedv: } \\
\text { levelek }\end{array}$ & $\begin{array}{l}\text { Kment et al. } \\
2009\end{array}$ \\
\hline $\begin{array}{l}\text { Aphis nerii F., } 1841 \\
\text { (leander-levéltetü) }\end{array}$ & $\begin{array}{l}\text { Hemiptera: } \\
\text { Aphididae }\end{array}$ & generalista & $\begin{array}{l}\text { növényi nedv: } \\
\text { szár, levelek }\end{array}$ & $\begin{array}{l}\text { Molnár et } \\
\text { al. 2010; } \\
\text { Bukovinszky et } \\
\text { al. } 2014\end{array}$ \\
\hline $\begin{array}{l}\text { Aphis gossypii G., } 1877 \\
\text { (uborka-levéltetű) }\end{array}$ & $\begin{array}{l}\text { Hemiptera: } \\
\text { Aphididae }\end{array}$ & generalista & $\begin{array}{l}\text { növényi nedv: } \\
\text { szár, levelek }\end{array}$ & $\begin{array}{l}\text { Molnár et al. } \\
2010\end{array}$ \\
\hline $\begin{array}{c}\text { Frankliniella } \\
\text { occidentalis } \text { P., } 1895 \\
\text { (nyugati virágtripsz) }\end{array}$ & $\begin{array}{l}\text { Thysanoptera: } \\
\text { Thripidae }\end{array}$ & generalista & $\begin{array}{l}\text { növényi nedv: } \\
\text { szár, levelek }\end{array}$ & Tóth 2017 \\
\hline
\end{tabular}


A méreggyilokfajok fogyasztói

$\mathrm{Az}$ általunk vizsgált, Európában őshonos méreggyilokfajokat (Vincetoxicum hirundinaria, Vincetoxicum pannonicum, Vincetoxicum nigrum és a Vincetoxicum rossicum) összesen nyolc őshonos specialista rovarfaj és kilenc őshonos generalista rovarfaj fogyasztja (4., 5. táblázat). Ezen belül a hazánkban bennszülött magyar méreggyilokon eddig csak egy specialista fajt, a tündöklő méreggyiloklevelészt (Chrysochus asclepiadeus Pallas, 1773) és egy generalista fajt, a lovagbodobácsot (Lygaeus equestris L., 1758) figyelték meg táplálkozás közben (Fenyősi 2018).

Észak-Amerikában mintegy kilenc generalista rovarfajt találtak, amelyek a Vincetoxicum rossicum és a Vincetoxicum nigrum fajokat is fogyasztják. Ezeken kívül két generalista rovarfaj fordult elő csak a Vincetoxicum nigrum-on, míg két másik generalista rovarfajt csak a Vincetoxicum rossicum-on találtak meg (6. táblázat). Nem tudunk arról, hogy Észak-Amerikában megjelentek volna a méreggyilokfajok Európában őshonos specialista rovar fogyasztói. A méreggyilokfajok eredeti elterjedési területén előforduló specialista rovarfajok közül két fajt (Hypena opulenta Christoph, 1877 és a Chrysochus asclepiadeus) a Vincetoxicum rossicum és a Vincetoxicum nigrum inváziója elleni védekezés céljából betelepítették Észak-Amerikába.

4. táblázat. A méreggyilok-fajok rovar fogyasztóinak száma.

\begin{tabular}{ccc}
\hline & Specialista fajok & Generalista fajok \\
\hline Európában őshonos, Vincetoxicum fajokat fogyasztó rovar & 8 & 9 \\
Ebből Észak-Amerikában megjelent/oda átvitt & 2 & 0 \\
$\begin{array}{c}\text { Észak-Amerikában a selyemkóróról a Vincetoxicum fajok- } \\
\text { ra (4 faj) váltott = Vincetoxicum új fogyasztója }\end{array}$ & 0 & 0 \\
$\begin{array}{c}\text { Észak-Amerikában Vincetoxicum fajokat fogyasztó ősho- } \\
\text { nos rovar = Vincetoxicum új fogyasztója }\end{array}$ & 1 & 0 \\
\hline
\end{tabular}

Tápnövényváltás

Az eddigi irodalmi adatok alapján Európában a méreggyilokfajokat fogyasztó specialista rovarok közül nem találtak egy fajt sem, amely a közönséges selyemkórót fogyasztotta volna. Ehhez hasonlóan Észak-Amerikában sem találtak olyan ott őshonos, közönséges selyemkórót fogyasztó rovart, amely az inváziós méreggyilokfajokat is fogyasztotta volna. A pompás királylepkék alkalmanként méreggyilokfajokra (Vincetoxicum rossicum, Vincetoxicum nigrum) teszik a petéiket, de a lárvák nem tudnak kifejlődni, elpusztulnak (Schlapfer et al. 2005). 
5. táblázat. A méreggyilok-fajokat leggyakrabban fogyasztó rovarokfajok az öshazájukban (Európa).

\begin{tabular}{|c|c|c|c|c|}
\hline Faj neve & $\begin{array}{l}\text { Rendszertani } \\
\text { besorolás }\end{array}$ & $\begin{array}{l}\text { Táplálkozás } \\
\text { típusa }\end{array}$ & $\begin{array}{l}\text { Növényi rész } \\
\text { fogyasztása }\end{array}$ & Hivatkozás \\
\hline $\begin{array}{l}\text { Abrostola asclepiadis Den. } \\
\text { \& Sch., } 1775 \text { (barnafoltos } \\
\text { ezüstbagoly) }\end{array}$ & $\begin{array}{l}\text { Lepidoptera: } \\
\text { Noctuidae }\end{array}$ & specialista & levelek & $\begin{array}{l}\text { Weed et al., 2011; } \\
\text { Hazlehurst 2011, } \\
\text { Kalske et al. 2012, } \\
\text { Laukkanen } 2014\end{array}$ \\
\hline $\begin{array}{l}\text { Chrysolina aurichalcea ssp. } \\
\text { asclepiadis M., } 1825\end{array}$ & $\begin{array}{l}\text { Coleoptera: } \\
\text { Chrysomelidae }\end{array}$ & specialista & levelek & Weed et al. 2011 \\
\hline $\begin{array}{c}\text { Chrysolina aurichalcea ssp. } \\
\text { bohemia } \text { M., } 1825\end{array}$ & $\begin{array}{l}\text { Coleoptera: } \\
\text { Chrysomelidae }\end{array}$ & specialista & levelek & Weed et al. 2011 \\
\hline $\begin{array}{c}\text { Euphranta connexa F., } \\
1794\end{array}$ & $\begin{array}{c}\text { Diptera: } \\
\text { Tephritidae }\end{array}$ & specialista & termés, magok & $\begin{array}{l}\text { Kalske et al. 2012, } \\
\text { Laukkanen } 2014\end{array}$ \\
\hline $\begin{array}{c}\text { Contarinia asclepiadis } \\
\text { G., } 1863\end{array}$ & $\begin{array}{c}\text { Diptera: } \\
\text { Cecidomyiidae }\end{array}$ & specialista & magok & Tewksbury et al. 2002 \\
\hline $\begin{array}{c}\text { Contarinia vincetoxici } \\
\text { K., } 1909\end{array}$ & $\begin{array}{c}\text { Diptera: } \\
\text { Cecidomyiidae }\end{array}$ & specialista & magok & Tewksbury et al. 2002 \\
\hline Hypena opulenta C., 1877 & $\begin{array}{l}\text { Lepidoptera: } \\
\text { Erebidae }\end{array}$ & specialista & levelek & $\begin{array}{l}\text { Weed \& Casagrande } \\
\text { 2010, Weed et al. } \\
\text { 2011, Hazlehurst et } \\
\text { al. } 2012\end{array}$ \\
\hline $\begin{array}{c}\text { Chrysochus asclepiadeus } \\
\text { P., } 1773 \text { (tündöklő } \\
\text { méreggyiloklevelész) }\end{array}$ & $\begin{array}{l}\text { Coleoptera: } \\
\text { Chrysomelidae }\end{array}$ & specialista & $\begin{array}{l}\text { gyökerek, } \\
\text { levelek }\end{array}$ & $\begin{array}{l}\text { Weed et al. 2011, } \\
\text { deJonge et al. } 2019 \text {, } \\
\text { Fenyősi } 2018\end{array}$ \\
\hline $\begin{array}{c}\text { Lygaeus equestris L., } 1758 \\
\text { (közönséges lovagbodo- } \\
\text { bács) }\end{array}$ & $\begin{array}{l}\text { Colepotera: } \\
\text { Lygaeidae }\end{array}$ & generalista & $\begin{array}{l}\text { növényi nedv, } \\
\text { magok }\end{array}$ & $\begin{array}{l}\text { Kugelberg 1977, } \\
\text { Laukkaen 2014, } \\
\text { Fenyősi } 2018\end{array}$ \\
\hline $\begin{array}{c}\text { Tropidothorax leucopterus } \\
\text { G., } 1778 \text { (vadpaprika } \\
\text { bodobács) }\end{array}$ & $\begin{array}{l}\text { Colepotera: } \\
\text { Lygaeidae }\end{array}$ & generalista & levelek nedve & Tullberg et al. 2000 \\
\hline $\begin{array}{l}\text { Otiorhynchus pinastri H., } \\
1795 \text { (fenyőrontó gyalogor- } \\
\text { mányos) }\end{array}$ & $\begin{array}{l}\text { Coleoptera: } \\
\text { Curculionidae }\end{array}$ & generalista & gyökerek & Kizub \& Slutsky 2019 \\
\hline $\begin{array}{c}\text { Graphosoma italicum } \\
\text { M., } 1766 \text { (csíkos pajzsos } \\
\text { poloska) }\end{array}$ & $\begin{array}{l}\text { Hemiptera: } \\
\text { Pentatomoidae }\end{array}$ & generalista & $\begin{array}{l}\text { növényi nedv, } \\
\text { levelek, szár }\end{array}$ & $\begin{array}{l}\text { Weed \& Casagrande } \\
2010\end{array}$ \\
\hline $\begin{array}{l}\text { Sparganothis pilleriana } \\
\text { Den. \& Sch., } 1775 \\
\text { (szölöilonca) }\end{array}$ & $\begin{array}{l}\text { Lepidoptera: } \\
\text { Tortricidae }\end{array}$ & generalista & levelek & $\begin{array}{c}\text { Milbrath 2010, } \\
\text { DiTommaso et al. } 2005\end{array}$ \\
\hline $\begin{array}{c}\text { Exosoma lusitanicum L., } \\
1767\end{array}$ & $\begin{array}{l}\text { Coleoptera: } \\
\text { Chrysomelidae }\end{array}$ & generalista & levelek & DiTommaso et al. 2005 \\
\hline $\begin{array}{c}\text { Philaenus spumarius L., } \\
1758\end{array}$ & $\begin{array}{l}\text { Hemiptera: } \\
\text { Cercopidae }\end{array}$ & generalista & levelek, szár & DiTommaso et al. 2005 \\
\hline $\begin{array}{l}\text { Scopula umbelaria } \mathrm{H} ., 1813 \\
\text { (világossávos araszoló) }\end{array}$ & $\begin{array}{l}\text { Lepidoptera: } \\
\text { Geometridae }\end{array}$ & generalista & levelek & DiTommaso et al. 2005 \\
\hline $\begin{array}{c}\text { Nothris congressariella } \\
\text { B., } 1858\end{array}$ & $\begin{array}{l}\text { Lepidoptera: } \\
\text { Gelechiidae }\end{array}$ & generalista & levelek & DiTommaso et al. 2005 \\
\hline
\end{tabular}


6. táblázat. A méreggyilok-fajokat leggyakrabban fogyasztó generalista rovarfajok új az elterjedési területükön (Észak-Amerika).

\begin{tabular}{|c|c|c|c|}
\hline Faj neve & $\begin{array}{l}\text { Rendszertani beso- } \\
\text { rolás }\end{array}$ & $\begin{array}{l}\text { Növényi rész fo- } \\
\text { gyasztása }\end{array}$ & Hivatkozás \\
\hline $\begin{array}{l}\text { Tetranychus urticae } \\
\text { C. L. K., } 1836 \text { (kö- } \\
\text { zönséges takácsatka) }\end{array}$ & Acari: Tetranychidae & növényi nedv: levelek & Milbrath, 2010 \\
\hline $\begin{array}{c}\text { Aulacorthum solani } \\
\text { K., } 1843\end{array}$ & Hemiptera: Aphididae & növényi nedv: levelek & $\begin{array}{c}\text { Milbrath, Biazzo } \\
2012\end{array}$ \\
\hline $\begin{array}{l}\text { Heliococcus osborni } \\
\text { S., } 1902\end{array}$ & $\begin{array}{c}\text { Hemiptera: } \\
\text { Pseudococcidae }\end{array}$ & növényi nedv: levelek & Milbrath, 2010 \\
\hline Thrips tabaci L. 1889 & $\begin{array}{c}\text { Thysanoptera: } \\
\text { Thripidae }\end{array}$ & levelek, virágok & Milbrath, 2010 \\
\hline $\begin{array}{c}\text { Anormenis } \\
\text { septentrionalis } \\
\text { S., } 1889\end{array}$ & Hemiptera: Flatidae & $\begin{array}{c}\text { növényi nedv: szár, } \\
\text { levelek }\end{array}$ & Milbrath, 2010 \\
\hline Chaitophorus sp. & Hemiptera: Aphididae & növényi nedv: levelek & Milbrath, 2010 \\
\hline Drepanaphis sp. & Hemiptera: Aphididae & növényi nedv: levelek & Milbrath, 2010 \\
\hline Iziphya sp. & Hemiptera: Aphididae & növényi nedv: levelek & Milbrath, 2010 \\
\hline $\begin{array}{c}\text { Monellia caryella } \mathrm{F} ., \\
1885\end{array}$ & Hemiptera: Aphididae & növényi nedv: levelek & Milbrath, 2010 \\
\hline $\begin{array}{l}\text { Lepidosaphes ulmi } \\
\text { L., } 1758 \text { (közönséges } \\
\text { kagylós pajzstetü) }\end{array}$ & $\begin{array}{l}\text { Hemiptera: } \\
\text { Diaspididae }\end{array}$ & $\begin{array}{c}\text { növényi nedv: szár, } \\
\text { levélnyél }\end{array}$ & Milbrath, 2010 \\
\hline $\begin{array}{l}\text { Poecilocapsus } \\
\text { lineatus F., } 1798\end{array}$ & Hemiptera: Miridae & növényi nedv: levelek & Milbrath, 2010 \\
\hline $\begin{array}{c}\text { Aphis spiraecola P., } \\
1914\end{array}$ & Hemiptera: Aphididae & növényi nedv: levelek & Milbrath, 2010 \\
\hline $\begin{array}{l}\text { Chorizococcus sp. } \\
\text { prob. dentatus L., } \\
1930\end{array}$ & $\begin{array}{c}\text { Hemiptera: } \\
\text { Pseudococcidae }\end{array}$ & növényi nedv: levelek & Milbrath, 2010 \\
\hline
\end{tabular}

\section{Diszkusszió}

A selyemkóró estében a kereséseket Európára vonatkozóan végeztük, azonban sok cikket találtunk kifejezetten magyarországi vizsgálatokról, hiszen Európa többi országához képest hazánkban van a selyemkórónak a legnagyobb elterjedési területe. A hazai cikkekben talált információk Európa más országaiban előforduló selyemkóró állományokra is igazak lehetnek. 
A közönséges selyemkóró fogyasztására Észak-Amerikában tíz rovarfaj specializálódott (van Zandt és Agrawal 2004, Agrawal et al. 2005), ezen fajok csökkentik a selyemkóró állományait és gátolják a terjedését az eredeti elterjedési területén (van Zandt és Agrawal 2004, Agrawal et al. 2005). Ugyanakkor az áttekintett irodalom alapján a közönséges selyemkórón Európában eddig csak generalista rovarfajok fogyasztását figyelték meg (Horváth 1984, Varga 1994, Molnár et al. 2010, Tóth 2017), pedig már több mint 300 éve jelen van a kontinensen (Bagi 2004). Jelenlegi ismereteink szerint ezek károsításának mértéke nem jelentős, így valószínűleg nem korlátozzák a faj terjedését.

Az Európában őshonos méreggyilokfajokat Európában nyolc specialista és kilenc generalista rovar fogyasztja és ezek a rovarok valószínüleg hozzájárulnak a méreggyilokfajok populáció-méretének állandóságához (Tewksbury et al. 2002). Az európai méreggyilokfajokat fogyasztó rovarok nem őshonosak Észak-Amerikában, és még nem jelentek meg, mint új jövevényfajok. A méreggyilokfajokat Észak-Amerikában néhány őshonos generalista rovar fogyasztja, de károkozásuk nem jelentős hatású a növényekre (Milbrath, 2010, Milbrath és Biazzo 2012).

Összességében azt találtuk, hogy mind a selyemkóró, mind a méreggyilokfajok esetén az eredeti elterjedési területükön számos specialista és generalista rovarfaj fogyasztotta őket, ugyanakkor az új elterjedési területükön az őket fogyasztó specialista fajok közül spontán még egy sem jelent meg, valamint generalista fogyasztót (akár mindkét területen elterjedtet, akár újat) is jóval kevesebbet figyeltek meg. Mindez arra utal, hogy közönséges selyemkóró és az inváziós méreggyilokfajok is megszabadulhattak fogyasztóik egy részétől, és ez hozzájárulhat a sikeres inváziójukhoz.

Eddigi irodalmi adatok alapján Európában a méreggyilokfajokat fogyasztó specialista rovarok közül nem találtak olyan rovarfajt, amely áttért volna a közönséges selyemkóró fogyasztására. Ehhez hasonlóan Észak-Amerikában sem találtak olyan közönséges selyemkórót fogyasztó rovart, amely az inváziós méreggyilokfajokat fogyasztotta volna. Egyedül a királylepke hernyóját figyelték meg az inváziós méreggyilokfajokon táplálkozni, de az állat nem tudott kifejlődni az új tápnövényen. Tehát sikeres spontán tápnövény-váltásra eddig egyik faj specialista rovarfogyasztója esetén sem volt példa.

Észak-Amerikában számos kutató vizsgálta, hogy a méreggyilokfajok ellen mely rovarok lehetnek hatásosak a biológiai védekezésben (Weed és Casagrande 2010, Weed et al. 2010, Weed et al. 2011, deJonge et al. 2019, Milbrath et al. 2019, deJonge et al. 2020). Milbrath et al. (2019) vizsgálata alapján az Európában öshonos méreggyilokfajokra specializálódott barnafoltos ezüstbagoly (Abrostola asclepiadis Denis \& Schiffermüller, 1775) nem bizonyult hatékonynak biológiai védekezési programokban a Vincetoxicum rossicum ellen. deJonge et al. (2019) 
vizsgálatai alapján egy Európában öshonos levélbogár, a Chrysochus cobaltinus LeConte, 1857 lárvái fogyasztják a Vincetoxicum rossicum leveleit, ezért biológiai védekezési programokban ígéretesnek tekintik, de további vizsgálatok szükségesek ennek bizonyítására. Viszont az Európából e célra betelepített specialista fajok, a Hypena opulenta lepke és a tündöklő méreggyiloklevelész (Chrysochus asclepiadeus) levélbogár-faj (Weed et al. 2011, Hazlehurst et al. 2012, 5. táblázat) hatékonyan csökkentik a méreggyilokfajok tömegességét Észak-Amerika északkeleti és középnyugati részén. Ez az eredmény is arra utal, hogy a méreggyilokfajok sikeres terjedése mögött esetleg a specialista fogyasztók hiánya állhat.

A közönséges selyemkóró elleni biológiai védekezésre Európában még nem vizsgáltak olyan rovarfajt/fajokat, amelyeket alkalmazni lehetne. A faj jelentős tömegessége miatt érdemes lenne további vizsgálatokat végezni azügyben, hogy mely rovarfajok fogyaszthatják (például gyökérkárosító fajok, levélfogyasztó rovarok, lepkék hernyói). Erre Magyarország különösen alkalmas lenne, hiszen Európán belül a selyemkóró hazánkban a legelterjedtebb.

Bár az új elterjedési területen mind a közönséges selyemkórót, mind az inváziós méreggyilokfajokat csak kevés generalista rovarfaj fogyasztotta, feltételezhetö, hogy más rovarfajok számára is fontos táplálékforrásként szolgálhatnak ezek a növények. Ugyanakkor a növényevő rovarok alkalmazása biológiai védekezési programokban kockázatos lehet, mivel ezek a rovarok más növényfajokat is károsíthatnak (Louda et al. 2005), és az őshonos rovarfaunára is negatív hatással lehetnek, ezért alkalmazásuk előtt mindenképpen részletes vizsgálatok szükségesek.

\section{Összefoglalás}

Észak-Amerikában a közönséges selyemkórót számos specialista és generalista rovarfaj fogyasztja, ami hatással lehet a populációméretére is. Ugyanakkor Európában a specialista rovarfogyasztói nem jelentek meg, itt csak néhány őshonos rovar fogyasztja. Ez arra utal, hogy a selyemkóró sok rovar fogyasztótól megszabadulhatott az új elterjedési területén, tehát a sikeressége mögött esetleg az ellenségektől való megszabadulás állhat.

A selyemkóróval közel rokon, Európában őshonos méreggyilokfajokat eredeti elterjedési területükön nyolc őshonos specialista rovarfaj, és kilenc generalista rovarfaj fogyasztja. Ugyanakkor a két, Észak-Amerikában invázióssá vált méreggyilokfajon új elterjedési területükön csak néhány generalista rovar fogyasztja, károkozásuk nincs jelentős hatással a növények populációjára. Viszont az Észak-Amerikában indított, méreggyilokfajok elleni biológiai védekezési programok - melyek során Európából származó méreggyilok specialista rovaro- 
kat használnak - sikeresnek bizonyultak, ami arra utal, hogy a méreggyilokfajok sikeres inváziójához is hozzájárult az ellenségeiktől való megszabadulás.

Az eddigi irodalmi adatok alapján még nem találtak olyan rovarfajt Európában, amely méreggyilokfajok fogyasztásáról váltott volna át a selyemkóróra, és ehhez hasonlóan Észak-Amerikában sem találtak még olyan rovart, amely a selyemkóróról váltott volna át az ott inváziós méreggyilokfajokra. Azonban nem lehet kizárni annak lehetőségét, hogy a jövőben gazdanövény-váltás történhet, emiatt mindenképpen érdemes a selyemkóró és a méreggyilokfajok rovarfogyasztó közösségeit monitorozni.

Köszönetnyilvánitás - A kutatást a Nemzeti Kutatási, Fejlesztési és Innovációs Hivatal (NKFIH FK128465) és az ELTE Biológia Doktori Iskola Ökológia, Konzervációbiológia és Szisztematika Doktori Program támogatta.

\section{Irodalomjegyzék}

Agosta, S. J. (2006): On ecological fitting, plant-insect associations, herbivore host shifts, and host plant selection. Oikos 114: 556-565. https://doi.org/10.1111/j.2006.0030-1299.15025.x

Agrawal, A. A., Kotanen, P. M. (2003): Herbivores and the success of exotic plants: a phylogenetically controlled experiment. Ecology Letters 6: 712-715. https://doi.org/10.1046/j.1461$\underline{0248.2003 .00498 . x}$

Agrawal, A. A. (2004): Plant defense and density dependence in the population growth of herbivores. American Naturalist 164: 113-120. https://doi.org/10.1086/420980

Agrawal, A. A. (2005): Natural selection on a common milkweed (Asclepias syriaca) by a community of specialized insect herbivores. Evolutionary Ecology Research 7: 651-667.

Agrawal, A. A., Kotanen, M. P., Mitchell, E. C., Power, G. A., Godsoe, W., Klironomos, J. (2005): Enemy release? An experiment with congeneric plant pairs and diverse above- and belowground enemies. Ecology 86. 11: 2979-2989. https://doi.org/10.1890/05-0219

Agrawal, A. A., Fishbein, M. (2006): Plant defense syndromes. Ecology 87: S132-S149. https://doi. org/10.1890/0012-9658(2006)87[132:PDS]2.0.CO;2

Bagi, I. (2004): Selyemkóró. In: Mihály B., Botta-Dukát Z. (szerk.): Biológiai inváziók Magyarországon. Özönnövények. A KvVM Természetvédelmi Hivatalának Tanulmánykötetei 9. Természet BÚVÁR Alapítvány Kiadó Budapest, pp. 319-336.

Bagi, I., Bakacsy, L. (2012): Közönséges selyemkóró (Asclepias syriaca). In: Csiszár Á. (szerk.): Inváziós növényfajok Magyarországon. Nyugat-magyarországi Egyetem Kiadó, Sopron, pp. 183-188.

Bascompte, J., Jordano, P. (2007): Plant-animal mutualistic networks: The architecture of biodiversity. Annual Review Ecology, Evolution and Systematics 38: 567-93. https://doi.org/10.1146/ annurev.ecolsys.38.091206.095818

Betz, R. F., Rommel, W. R., Dichtl, J. J. (2000): Insect herbivores of 12 milkweed (Asclepias) species. In: Warwick, C. (ed.): Proceedings of the Fifteenth North American Prairie Conference. Natural Areas Association, Bend, pp. 7-19.

Bhowmik, P. C. (1994): Biology and control of common milkweed (Asclepias syriaca). Reviews of Weed Science 6: 227-250. https://works.bepress.com/prasanta_bhowmik/3/ 
Biazzo, J., Milbrath, L. R. (2019): Response of pale swallowwort (Vincetoxicum rossicum) to multiple years of mowing. Invasive Plant Science and Management 3: 169-175. https://doi. org/10.1017/inp.2019.22

Bingham, R. A., Agrawal, A. A. (2010): Specificity and trade-offs in the induced plant defence of common milkweed Asclepias syriaca to two lepidopteran herbivores. Journal of Ecology 5: 1014-1022. https://doi.org/10.1111/j.1365-2745.2010.01681.x

Birnbaum, S. S. L., Abbot, P. (2018): Insect adaptations toward plant toxins in milkweed-herbivores systems - a review. Entomologia Experimentalis et Applicata 166: 357-366. https://doi. org/10.1111/eea.12659

Botta-Dukát Z. (2008): Invasion of alien species to Hungarian (semi-)natural habitats. Acta Botanica Hungarica 50 (Suppl.): 219-227. https://doi.org/10.1556/abot.50.2008.suppl.11

Bukovinszky, T., Gols, R., Agrawal, A. A., Roge, C., Bezemer, T. M., Biere, A., Harvey, J. A. (2014): Reciprocal interactions between native and introduced populations of common milkweed, Asclepias syriaca, and the specialist aphid, Aphis nerii. Basic and Applied Ecology 15: 444-452. https://doi.org/10.1016/j.baae.2014.07.004

Casagrande, R. A., Dacey, J. E. (2007): Monarch butterfly oviposition on swallow-worts (Vincetoxicum spp.). Environmental Entomology 36: 631-636. https://doi.org/10.1603/0046-225X(2007)3 6[631:MBOOSV]2.0.CO;2

Callaway, R. M., Ridenour, W. M. (2004): Novel weapons: invasive success and the evolution of increased competitive ability. Frontiers in Ecology and the Environment 2: 436-433. https://doi. org/10.1890/1540-9295(2004)002[0436:NWISAT]2.0.CO;2

Carpenter, D., Cappuccino, N. (2005): Herbivory, time since introduction and the invasiveness of exotic plants. Journal of Ecology 93: 315-321. https://doi.org/10.1111/j.1365-2745.2005.00973.x

Chaplin, S. J., Chaplin, S. B. (1981): Growth dynamics of a specialized milkweed seed feeder (Oncopeltus fasciatus) on seeds of familiar and unfamiliar milkweed (Asclepias spp.). Entomologia Experimantalis et Applicat 3: 345-355. https://doi.org/10.1111/j.1570-7458.1981.tb03078.x

Cincotta, L. C., Adams, M. J., Holzapfel, C. (2009): Testing the enemy release hypothesis: a comparison of foliar insect herbivory of the exotic Norway maple (Acer platanoides L.) and the native sugar maple (A. saccharum L.). Biological Invasions 11: 379-388. https://doi.org/10.1007/ $\underline{\text { s10530-008-9255-9 }}$

Colautti, R. I., Ricciardi, A., Grigorovic, I. A., MacIsaac, H. J. (2004): Is invasion success explained by the enemy release hypothesis? Ecology Letters 7: 721-733. https://doi.org/10.1111/j.1461_0248.2004.00616.x

Csiszár, Á. (2012): Inváziós növényfajok Magyarországon. Sopron. Nyugat-magyarországi Egyetem Kiadó, Sopron, 364 p.

deJonge, R. B., Bourchier, R. S., Jones, I. M., Smith, S. M. (2019): Predicting the outcome of potential novel associations: interactions between the invasive Vincetoxicum rossicum and native western Chrysochus beetles. Biological Invasions 21: 3169-3184. https://doi.org/10.1007/ s10530-019-02043-4

deJonge, R. B., Jones, I. M., Bourchier, R. S., Smith, S. M. (2020): Interpreting host-test results for classical biological control candidates: Can the study of native congeners improve the process? Biological Control 145: 104237. https://doi.org/10.1016/j.biocontrol.2020.104237

Ding, J., Blossey, B., Du, Y., Zheng, F. (2006): Impact of Galerucella birmanica (Coleoptera: Chrysomelidae) on growth and seed production of Trapa natans. Biological Control 37: 338 345. https://doi.org/10.1016/j.biocontrol.2005.12.003

DiTommaso, A., Losey, J. E. (2003): Oviposition preference and larval performance of monarch butterflies (Danaus plexippus) on two invasive swallow-wort species. Entomologia Experimantalis et Applicata 108: 205-209. https://doi.org/10.1046/j.1570-7458.2003.00089.x 
DiTommaso, A., Lawlor, M. F., Darbyshire, J. S. (2005): The biology of invasive alien plants in Canada. 2. Cynanchum rossicum (Kleopow) Borhidi [= Vincetoxicum rossicum (Kleopow) Barbar.] and Cynanchum louiseae (L.) Kartesz. Gandhi [= Vincetoxicum nigrum (L.) Moench]. Canadian Journal of Plant Science 85: 243-263. https://doi.org/10.4141/P03-056

DiTommaso, A., Milbrath, L. R., Bittner, T., Wesley, F. R. (2013): Pale swallowwort (Vincetoxicum rossicum) response to cutting and herbicides. Invasive Plant Science and Management 6: 381-390. https://doi.org/10.1614/IPSM-D-12-00078.1.

da Ros, N., Ostermeyer, R., Roques A., Raimbault J. P. (1993): Insect damage to cones of exotic conifer species introduced in arboreta. 1. Interspecific variations within the genus Picea. Journal of Applied Entomology 115: 113-133. https://doi.org/10.1111/j.1439-0418.1993.tb00371.x

Fenyősi, Zs. (2018): A magyar méreggyilok (Vincetoxicum pannonicum (Borhidi) Holub 1967) ízeltlábú fogyasztói. Natura Somogyiensis 32: 121-124. http://doi.org/10.24394/NatSom.2018.32.121

Fordyce, A. J., Malcolm, B. S. (2000): Specialist weevil, Rhyssomatus lineaticollis, does not spatially avoid cardenolide defense of common milkweed by oviposing into pith tissue. Journal of Chemical Ecology 26: 2857-2874.

Han, X., Dendy, P. S., Garrett, A. K., Fang, L., Smith, D. M. (2008): Comparison of damage to native and exotic tallgrass prairie plants by natural enemies. Plant Ecology 198: 197-210. https://doi. org/10.1007/s11258-008-9395-0

Haye, T., Goulet, H., Mason, P. G., Kuhlmann, U. (2005): Does fundamental host range match ecological host range? A retrospective case study of a Lygus plant bug parasitoid. Biological Control 35: 55-67. https://doi.org/10.1016/j.biocontrol.2005.06.008

Hazlehurst, A. F., Weed, A. S., Tewksbury, L., Casagrande, A. R. (2012): Host specificity of Hypena opulenta: A potential biological control agent of Vincetoxicum in North America. Entomological Society of America 41: 841-848. http://dx.doi.org/10.1603/EN12093

Herrick, J. N., Mcavoy, J. T., Snyder, L. A., Salom, M. S., Kok, T. L. (2012): Host-range testing of Eucryptorrhynchus brandti (Coleoptera: Curculionidae), a candidate for biological control of tree-of-heaven, Ailanthus altissima. Environmental Entomology 41: 118-124. https://doi. org/10.1603/EN11153

Hierro, J. L., Callaway, R. M. (2003): Allelopathy and exotic plant invasion. Plant and Soil 256: 29-39. https://doi.org/10.1023/A:1026208327014

Holdrege, C. (2010): The Story of an Organism: Common Milkweed. The Nature Institute, Ghent.

Horváth, Z. (1984): Adatok az Asclepias syriaca L. (Asclepiadaceae) magprodukciójának és csírázásbiológiájának komplex ismeretéhez. Növényvédelem 20: 158-165.

Hughes, L., Bazzaz F. A. (1997): Effect of elevated $\mathrm{CO}_{z}$ on interactions between the western flower thrips, Frankliniella occidentalis (Thysanoptera: Thripidae) and the common milkweed, Asclepias syriaca. Oecologia 109: 286-290. https://doi.org/10.1007/s004420050085

Hulme, P. E. (2009): Trade, transport and trouble: managing invasive species pathways in an era of globalization. Journal of Applied Ecology 1: 10-18. https://oi.org/10.1111/j.1365$\underline{2664.2008 .01600 . x}$

IUCN (2000). IUCN Guidelines for the Prevention of Biodiversity Loss Caused by Alien Invasive Species. Prepared by the SSC Invasive Species Specialist Group. Approved by the 51st Meeting of the IUCN Council, Gland Switzerland, February 2000. https://portals.iucn.org/library/efiles/ documents/Rep-2000-052.pdf

Jeschke, J. M. (2014): General hypotheses in invasion ecology. Diversity and Distributions 11: 1229-1234. https://doi.org/10.1111/ddi.12258

Jogesh, T., Carpenter, D., Cappuccino, N. (2008): Herbivory on invasive exotic plants and their non-invasive relatives. Biological Invasions 10: 797-804. https://doi.org/10.1007/s10530-008$\underline{9236-\mathrm{Z}}$ 
Julien, M. H., M. W. Griffiths (1998): Biological Control of Weeds. A World Catalogue of Agents and Their Target Weeds. CABI, Wallingford, $223 \mathrm{p}$.

Kalske, A., Muola, A., Laukkanen, L., Mutikainen, P., Leimu, R. (2012): Variation and constraints of local adaptation of a long-lived plant, its pollinators and specialist herbivores. Journal of Ecology 100: 1359-1372. https://doi.org/10.1111/j.1365-2745.2012.02008.x

Karban, R., Baldwin, I. T. (1997): Induced Responses to Herbivory. University of Chicago Press, Chicago, pp. 330.

Karban, R., Agrawal, A. A. (2002): Herbivore offense. Annual Review of Ecology, Evolution, and Systematics 33: 641-664. https://doi.org/10.1146/annurev.ecolsys.33.010802.150443

Keane, M. R., Crawley, J. M. (2002): Exotic plant invasions and the enemy release hypothesis. Trends in Ecology and Evolution 4: 164-170. http://dx.doi.org/10.1016/S0169-5347(02)02499_ $\underline{0}$

Kment, P., Štys, P., Exnerová, A., Tomšík, P., Baňař, P., Hradil, K. (2009): The distribution of Tropidothorax leucopterus in the Czech Republic and Slovakia (Hemiptera: Heteroptera: Lygaeidae). Acta Musei Moraviae, Scientiae Biologicae 94: 27-42.

Király, G. (szerk.) (2009): Új magyar füvészkönyv. Magyarország hajtásos növényei. Határozókulcsok. Aggteleki Nemzeti Park Igazgatóság, Jósvafö, 616 p.

Kizub, V. I., Slutsky, I. A. (2019): Contribution to the knowledge of the genus Otiorhynchus Germar, 1822 (Coleoptera: Curculionidae) fauna of Ukraine. Part 2. Munis Entomology and Zoology 14: $530-546$.

Kolar, C. S., Lodge, D. M. (2001): Progress in invasion biology: predicting invaders. Trends in Ecology and Evolution 16: 199-204. https://doi.org/10.1016/S0169-5347(01)02101-2

Kugelberg, O. (1977): Distribution, feeding habits and dispersal of Lygaeus equestris (Heteroptera) larvae in relation to food supply. Oikos 29: 398-406. https://www.jstor.org/stable/3543579

Laukkanen, L. (2014): Population genetics, food-plant specialization, and local adaptation of insect herbivores living in a fragmented landscape. Annales Universtatis Turkuensis, University of Turku, Turku. $48 \mathrm{p}$.

Levine, J. M., Vila, M., D’Antonio, C. M., Dukes, J. S., Grigulis, K., Lavorel, S. (2003): Mechanisms underlying the impacts of exotic plantinvasions. Proceedings of the Royal Society B: Biological Sciences 270: 775-781. https://doi.org/10.1098/rspb.2003.2327

Louda, S. M., Rand, T. A., Russell, F. L., Arnett, A. E. (2005): Assessment of ecological risks in weed biocontrol: Input from retrospective ecological analyses. Biological Control 35: 253-264. https://doi.org/10.1016/j.biocontrol.2005.07.022

Malcolm, S. B. (1991): Cardenolide-mediated interactions between plants and herbivores. In: Rosenthal, G. A., Berenbaum, M. R. (eds.): Herbivores: Their Interactions With Secondary Plant Metabolites. Volume 1. Academic Press, San Diego, pp. 251-296.

Markgraf, F. (1972): Asclepiadaceae. In: Tutin, T. G., Heywood, V. H., Burges, N. A., Moore, D. M., Valentine, V. H., Walter, S. M., Webb, D. A. (eds.): Flora Europea, Volume 3. Cambridge University Press, Cambridge. https://doi.org/10.5281/zenodo.305475

Maron, J. L., Vilà, M. (2001): When do herbivores affect plant invasion? Evidence for the natural enemies and biotic resistance hypotheses. Oikos 95: 361-373. https://doi.org/10.1034/j.16000706.2001.950301.x

Matter, F. S. (2001): Effects of above and below ground herbivory by Tetraopes tetraophthalmus (Coleoptera: Cerambycidae) on the growth and reproduction of Asclepias syriaca (Asclepidacae). Environmental Entomology 30: 333-338. http://doi.org/10.1603/0046-225X-30.2.333

McFadyen, R. E. C. (1998): Biological control of weeds. Annual Review of Entomology 43: 369393. https://doi.org/10.1146/annurev.ento.43.1.369 
Milbrath, L. R. (2010): Phytophagous arthropods of invasive swallow-wort vines (Vincetoxicum spp.) in New York. Environmental Entomology 39: 68-78. https://doi.org/10.1603/EN09116

Milbrath, L. R., Dolgovskaya, M., Volkovitsh, M., Sforza, H. F. R., Biazzo, J. (2019): Photoperiodic response of Abrostola asclepiadis (Lepidoptera: Noctuidae), a candidate biological control agent for swallow-worts (Vincetoxicum, Apocynaceae). Great Lakes Entomologist 52: 71-77. https:// scholar.valpo.edu/tgle/vol52/iss $2 / 5$

Mooney, K. A., Jones, P., Agrawal, A. A. (2008): Coexisting congeners: demography, competition, and interactions with cardenolides for two milkweed-feeding aphids. Oikos 117: 450-458. https://doi.org/10.1111/j.2007.0030-1299.16284.x

Molnár, N., Harkai, A., Setényi, R. (2010): Spatial patterns of Aphis gossypii (Sternorrhyncha: Aphididae) populations feeding on milkweed (Asclepias syriaca). Acta Phytopathologica et Entomologica Hungarica 1: 71-80. https://doi.org/10.1556/APhyt.45.2010.1.4

Muola, A., Mutikainen, P., Laukkanen, L., Lilley, M., Leimu, R. (2010): Genetic variation in herbivore resistance and tolerance: the role of plant life-history stage and type of damage. Journal of Evolutionary Biology 23: 2185-2196. https://doi.org/10.1111/j.1420-9101.2010.02077.x

Parker, J. D., Burkepile, D. E., Lajeunesse, M. J., Lind, E. M. (2012): Phylogenetic isolation increases plant success despite increasing susceptibility to generalist herbivores. Diversity and Distributions 18: 1-9. https://doi.org/10.1111/j.1472-4642.2011.00806.x

Pimentel, D., Zuniga, R., Morrison, D. (2005): Update on the environmental and economic costs associated with alien-invasive species in the United States. Ecological Economics. 52: 273-288. https://doi.org/10.1016/j.ecolecon.2004.10.002

Pyšek, P., Pyšek, A. (1995): Invasion by Heracleum mantegazzianum in different habitats in the Czech Republic. Journal of Vegetation Science 6: 711-718. https://doi.org/10.2307/3236442

Pyšek, P., Richardson, D. M., Rejmánek, M., Webster, G. L., Williamson, M., Kirschner, J. (2004): Alien plants in checklists and floras: towards better communication between taxonomists and ecologists. Taxon 53(1): 131-143. https://doi.org/10.2307/4135498

Rasmann, S., Agrawal, A. A, Cook, S. C., Erwin, A. C. (2009): Cardenolides, induced responses, and interactions between above- and belowground herbivores of milkweed (Asclepias spp.). Ecology 90: 2393-2404. https://doi.org/10.1890/08-1895.1

Richardson, D. M., Pyšek, P., Rejmánek, M., Barbour, G. M., Panetta, F. D., West, J. C. (2000a): Naturalization and invasion of alien plants: concepts and definitions. Diversity and Distributions 6: 93-107. https://doi.org/10.1046/j.1472-4642.2000.00083.x

Richardson, D. M., Allsopp, N., D’Antonio, C. M., Milton, S. J., Rejmánek, M. (2000b): Plant invasions: the role of mutualism. Biological Reviews 75: 65-93. https://doi.org/10.1111/j.1469$\underline{\text { 185X.1999.tb00041.X }}$

Schlaepfer, M. A., Sherman, P. W., Blossey, B., Runge, M. C. (2005): Introduced species as evolutionary traps. Ecology Letters 8: 241-246. https://doi.org/10.1111/j.1461-0248.2005.00730.x

Sheeley, S. E., Raynal, D. J. (1996): The distribution and status of species of Vincetoxicum in eastern North America. Bulletin of the Torrey Botanical Club 123: 148-156. https://doi. org $/ 10.2307 / 2996072$

Staerk, D., Christensen, J., Lemmich, E., Duus, J., Olsen, C., Jaroszewski, J. (2000): Cytotoxic activity of some phenanthroindolizidine N-oxide alkaloids from Cynanchum vincetoxicum. Journal of Natural Product and Plant Resources 63: 1584-1586. https://doi.org/10.1021/np0003443

Stinson, A. S. C., Schroeder, D., Marquardt, K. (1994): Investigations on Cyphocleonus achates (Fahr.) (Col., Curculionidae), a potential biological control agent of spotted knapweed (Centaurea maculosa Lam.) and diffuse knapweed (C. diffusa Lam.) (Compositae) in North America. Journal of Applied Entomology 117: 35-50. https://doi.org/10.1111/j.1439-0418.1994.tb00705.x 
Stout, J. C., Morales, C. L. (2009): Ecological impacts of invasive alien species on bees. Apidologie 40: 388-409. https://doi.org/10.1051/apido/2009023

Tabashnik, B.E. (1983): Host range evolution: the shift from native legume hosts to alfalfa by the butterfly Colias philodice eriphyle. Evolution 37: 150-162. https://doi.org/10.1111/j.1558-5646.1983. tb05523.x

Tewksbury, L., Casagrande, R. A., Gassmann, A. (2002): Swallow-worts. In: Van Driesche, R., Lyon, S., Blossey, B., Hoddle, M., Reardon, R. (eds.): Biological Control of Invasive Plants in the Eastern United States. USDA Forest Service Publication FHTET-2002-04, Morgantown, pp. 209-216.

Thomas, C. D., Ng, D., Singer, M. C., Mallet, J. L. B., Parmesan, C., Billington, H. L. (1987): Incorporation of a European weed into the diet of a North American herbivore. Evolution 41: 892-901. https://doi.org/10.1111/j.1558-5646.1987.tb05862.x

Tóth, T. (2017): Két mikroszkópikus gombafaj együttes károsítása szíriai selyemkórón (Asclepias syriaca L.) a Hajdúsági kistérségben. Agrártudományi Közlemények 72: 189-195. https://doi. org/10.34101/actaagrar/72/1614

Traveset, A., Richardson, D. M. (2006): Biological invasions as disruptors of plant reproductive mutualisms. Trends in Ecology and Evolution 21(4): 208-216. https://doi.org/10.1016/j. tree.2006.01.006

Tullberg, B. S., Gamberale-Stille, G., Solbreck, C. (2000): Effects of food plant and group size on predator defence: differences between two co-occurring aposematic Lygaeinae bugs. Ecological Entomology 25: 220-225. https://doi.org/10.1046/j.1365-2311.2000.00238.x

Vadász, Cs. (2015): Az inváziós növényfajok visszaszorításának tapasztalatai a Felső-kiskunsági Turjánvidéken. In: Csiszár, Á., Korda, M. (szerk.): Özönnövények visszaszoritásának gyakorlati tapasztalatai. ROSALIA kézikönyvek 3. Duna-Ipoly Nemzeti Park Igazgatóság, Budapest, pp. $177-184$

Vajda, L. (2015): Alternatíva-e a selyemkóró visszaszorítására a mechanikus eltávolítás a vegyszerezéssel szemben? In: Csiszár, Á., Korda, M. (szerk.): Özönnövények visszaszorításának gyakorlati tapasztalatai. ROSALIA kézikönyvek 3. Duna-Ipoly Nemzeti Park Igazgatóság, Budapest, pp. 185-186.

Van Zandt, P. A., Agrawal, A. A. (2004): Community-wide impacts of herbivore-induced plant responses in milkweed (Asclepias syriaca). Ecology 85: 2616-2629. https://doi.org/10.1890/03$\underline{0622}$

Varga, L. (1998): Selyemkóró (Asclepias syriaca). In: Csíbor I., Hartmann F., Princzinger G., Radvány B. (szerk.): Veszélyes-24. A leggyakoribb gyomnövények és az ellenük való védekezés. Mezőföldi Agrofórum Kft., Szekszárd, pp. 103-111.

Vilà, M., Maron, J. L., Marco, L. (2005): Evidence for the enemy release hypothesis in Hypericum perforatum. Oecologia 142: 474-479. https://doi.org/10.1007/s00442-004-1731-Z

Wang, Y., Ding, J., Zhang, G. (2008): Gallerucida bifasciata (Coleoptera: Chrysomelidae), a potential biological control agent for Japanese knotweed (Fallopia japonica). Biocontrol Science and Technology 18: 59-74. http://dx.doi.org/10.1080/09583150701742453

Weed, A. S., Casagrande, R. A. (2010): Biology and larval feeding impact of Hypena opulenta (Christoph) (Lepidoptera: Noctuidae): A potential biological control agent for Vincetoxicum nigrum and V. rossicum. Biological Control 53: 214-222. https://doi.org/10.1016/j.biocontrol.2009.12.004

Weed, A. S., Gassmann, A., Leroux, A. M., Casagrande, R. A. (2011): Performance of potential European biological control agents of Vincetoxicum spp. with notes on their distribution. Journal of Applied Entomology 135: 700-713. https://doi.org/10.1111/j.1439-0418.2010.01594.x 
Williams, H. A. (2004): Feeding records of true bugs (Hemiptera: Heteroptera) from Wisconsin. Great Lakes Entomologist 37: 16-29. https://scholar.valpo.edu/tgle/vol37/iss1/3

Wolfe, L. M. (2002): Why alien invaders succeed: support for the escape-from-enemy hypothesis. American Naturalist 160: 705-711. https://doi.org/10.1086/343872

You, W., Fan, S., Yu, D., Xie, D., Liu, C. (2014): An invasive clonal plant benefits from clonal integration more than a co-occurring native plant in nutrient-patchy and competitive environments. PLoS One 9(5): e97246. https://doi.org/10.1371/journal.pone.0097246

Young, J., Weed, A. S. (2014): Hypena opulenta (Erebidae): A European species for the biological control of invasive swallow-worts (Vincetoxicum spp.) in North America. Journal of the Lepidopterists'Society 68: 162-166. https://doi.org/10.18473/lepi.v68i3.a2

Züst, T., Rasmann, S., Agrawal, A. A. (2015): Growth-defense tradeoffs for two major anti-herbivore traits of the common milkweed Asclepias syriaca. Oikos 125(10): 1404-1415. https://doi. org/10.1111/oik.02075

\section{Internetes források:}

http1: https://gd.eppo.int/taxon/ASCSY/distribution

http2: http://apps.webofknowledge.com/WOS GeneralSearch input.do?product=WOS\&search mode $=$ GeneralSearch \&SID $=$ E6F9JYCE8KfOAgwNUU9\&preferencesSaved $=$

http3: https://scholar.google.com/

http4: https://www.fs.fed.us/wildflowers/plant-of-the-week/asclepias_syriaca.shtml

\section{Függelék:}

A cikkhez tartozó Online Függelékek a folyóirat honlapján találhatóak.

1. Függelék: A közönséges selyemkóró jellemzése és inváziójának rövid történte.

2. Függelék: A méreggyilokfajok jellemzése. 


\title{
The invasion of plant species: does the lack of enemies facilitate invasion? - A literature review of insects consuming common milkweed and related plants
}

\author{
Boglárka Berki ${ }^{1} \&$ Anikó Csecserits ${ }^{2}$ \\ ${ }^{1}$ Eötvös Loránd University, Department of Plant Taxonomy, Ecology and Theoretical \\ Biology, H-1117, Budapest, Pázmány Péter sétány 1/C, Hungary \\ ${ }^{2}$ Centre for Ecological Research, Institute of Ecology and Botany, \\ H-2163 Vácrátót, Alkotmány u. 2-4, Hungary \\ E-mail: berki.boglarka@ecolres.hu
}

Common milkweed (Asclepias syriaca) is one of the most prominent perennial herbaceous invasive species in Hungary. Form the closest relative species, native in Europe two Vincetoxicum species are invasive in North America. Both milkweed and Vincetoxicum species have significant chemical defense against insects, thus it is assumable that their successful invasion could be partly because of the lack of their specialist insect consumers. We compared the insect community consuming these plant species in their original and new distribution areas with a systematic literature review. In its original area of distribution, milkweed is consumed by ten insect species and Vincetoxicum species by eight specialists as well as several generalists. However, in the new distribution areas, the specialist consumers have not yet appeared in either case, only generalist consumers were observed with a smaller species number. Thus, it can be assumed that the successful invasion of these plant species may have been facilitated by the release from their specialist consumers.

Keywords: Asclepias syriaca, Vincetoxicum sp., dog-strangling vine, plant-feeding insects, plantinsect interaction, plant defense mechanisms 